\title{
International Tourists Satisfaction: Case of Jordan
}

\author{
Malek Mohammad AL-Majali \\ Correspondence: Malek Mohammad AL-Majali, Department of Business Administration and Marketing, Mu'tah \\ University, Jordan. E-mail: Drmalekalmajali@yahoo.com
}

Received: May 7, 2012 Accepted: May 30, $2012 \quad$ Online Published: August 8, 2012

doi:10.5539/ibr.v5n9p210 URL: http://dx.doi.org/10.5539/ibr.v5n9p210

\begin{abstract}
Although the global tourism industry's increasing growth in Jordan, the number of international tourists is reduces in giving rise to a widespread concern of their actual visit behavior. Jordan's tourism industry is experiencing irregular tourist visit aggravated by either or any of the following reasons; high visit risk, little hotel service, bad image of the hotel service or international tourist's dissatisfaction. Therefore, the present study aims to inspect the causal relationships between the antecedents of tourist satisfaction which are perceived risk, Jordan image and service climate. This study used a survey data of 500 international tourists who visited Jordan. Structural Equation Modeling (SEM) techniques (Amos 6.0) were used to evaluate the casual model. The findings of present study highlighted that the relationship between Jordan image and tourist satisfaction are significant and positive. In contrast, perceived risk and service climate yields insignificant impact on tourist satisfaction.
\end{abstract}

Keywords: tourist satisfaction, perceived risk, Jordan's image, service climate

\section{Introduction}

The Jordan Tourism Board (JTB) has classified six main tourism services and is promoting Jordan as a 'boutique' destination, which means Jordan as a whole destination is compounded of different products with no specialisation in one segment. These market segments include history and culture; religion and faith; leisure and wellness; ecology and nature; conferences and events and fun and adventure (JTB, 2005). Jordan is heavily concentrated on its archaeological inheritance such as Petra and Jerash as the most visited sites in the kingdom. However, Jerash is the second most attractive tourist site most visited after Petra, it lacks the infrastructure and superstructure and tourist services needed for the inflow of tourists (Harahsheh, 2010).

Tourism organization in Jordan is divided into four major bodies, namely, the public sector, public/private partnerships, the private sector and NGOs (Harahsheh, 2010). The public sector consists of the following bodies such as the Ministry of Tourism and Antiquities (Department of tourism and Antiquities), twelve visitor centres, the Royal Jordanian (RJ), Petra Regional Authority (PRA) and the Aqaba Special Economic Zone Authority (ASEZA). The second type is a public/private partnership represented by the Jordan Tourism Board (JTB) and its twelve offices abroad. Tourism becomes visible as a large major growing segment in the global economy. This industry could play a vital role in supporting a country's trade performance. Therefore, a lot of national governments have sought to develop their competitive position with respect to the global tourism market. Thus, governments have started establishing local organizations that are related to promoting their destination abroad (Faulkner, 1992).

In the Jordanian Tourism arena, the agents and law-makers face a lot of troubles such as the tourists' satisfaction and decrease in the number of international tourists (Hamid, 2007). The numbers of international tourists decrease between the years 2006 which was 6,712,804 and declined gradually to 5,413.919 in year 2009 in Jordan (MoTA, 2010). This indicates that the Jordan tourism has been facing the problems of not receiving the expected number of international tourists in spite of extensive marketing efforts from MoTA. However, the factors that cause tourist satisfaction could be improved to increase the positive affect of tourist's behavior towards Jordan. This is involves many interrelated factors (perceived risk, image, service climate, and so on) (Al Muala, 2010). Thus, predicting of tourist satisfaction remains an important facet in the international tourism market. In order to achieve the objectives of the present research, the researcher believes that there are a good number of important related relationships that should be discussed with tourist satisfaction as shown in the following section. 


\section{Literature Review}

In 1988, customer satisfaction defines as the customer's reaction to the estimation of the perceived variation between previous anticipations and actual performance (Ueltschy \& Krampf, 2001). This study used three constructs as antecedents of satisfaction which are Jordan image, perceived risk and service climate, the researcher confirmed that the satisfaction factor can be predicted by these constructs which will be discuss later in the next section.

\subsection{Perceived Risk and Satisfaction}

Many studies discussed the influence of the perceived risk satisfaction factor in general; some of these studies found that there is a significant and negative relationship (Celik, 2008; Amoroso \& Hunsinger, 2008; Wong \& Yeh, 2009). In contrast, other studies found that there is an insignificant and negative relationship between perceived risk and satisfaction (Udo et al., 2008). This study focused on the relationship between perceived risk and tourist satisfaction. Hence, the first hypothesis formulated is:

\section{H1: Perceived risk is negatively related to tourist satisfaction.}

\subsection{Jordan's Image and Satisfaction}

In this connection, most of the previous studies found a significant and positive relationship between image and satisfaction (Andreassen \& Lindestad, 1998; Bigne et al., 2001; Chen \& Tsai, 2007; Chi \& Qu, 2008; Xia et al., 2009). There are a few previous studies have been conducted between service climate, Jordan image and perceived risk on tourist satisfaction. This study will examine the relationship between this variables and tourist satisfaction. Many studies focused on restaurant image or hotel image but there is a lack in previous studies examining a country image (Ryu et al., 2007; Chi \& Qu, 2008; Xia et al., 2009). Thus, the second hypothesis formulated is:

\section{H2: Jordan's Image is positively related to tourist satisfaction.}

\subsection{Service Climate and Satisfaction}

Service climate and quality and customer satisfaction become the priority of both manufacturers and service providers in the increasingly intensified competition for customers. However, findings regarding service quality and customer satisfaction are rather divergent and related studies are fragmented (Wang, 2004), especially for the complicated interrelationships among them. Thus, less is known about the relative impacts of quality-related factors and customer satisfaction. Thus, there are many studies conducted in many settings to examine the relationship between service climate, service quality and satisfaction. Furthermore, most of the studies discussed the influence of the service climate factor in general. The main reason for study this linkage, there are inconsistent results, some of these studies have found a significant impacts (Andreassen \& Lindestad, 1998; Choi \& Chu, 2000; Iglesias \& Guillen, 2004; Wang et al., 2004; Aydin \& Ozer, 2005; Yoo \& Park, 2007; Udo et al., 2008; Rodriguez et al., 2009) while some studies found that there was an insignificant relationship (Alhroot, 2007). Hence, the third hypothesis formulated is:

\section{H3: Service climate is positively related to tourist satisfaction.}

\section{Methodology}

This is a field study consisting mainly quantitative approach to research. The unit of analysis is 500 respondents were identified from the Dead Sea area of Jordan during their visit to Jordan in the period from December 10, 2010 until March 10, 2011 around twelve weeks. Out of 500 questionnaires distributed, 110 were unreturned, and 89 questionnaires were incomplete. After that Mahalanobis distance $\left(\mathrm{D}^{2}\right)$ was conducted to create out outlier cases. Outlier result indicates that only10 dataset were removed due to $\mathrm{D}^{2}$ values greater than $\chi^{2}$ value. For Univariate normality test, Z-skewness scores greater than +3 or -3 were missing. Therefore, every item is considered to be normal data. Thus, only two hundred ninety one 291 questionnaires remain for final analysis, Giving a response rate of $58.2 \%$.

Consequently, some statistical validity tests conducted such as composite reliability tests, reliability test, Confirmatory Factor Analysis (CFA) for construct convergent validity, discriminate validity for multicollinearity treatment, descriptive analysis and correlation. After this, Structural Equation Modeling (SEM) analysis using AMOS 6.0 was conducted.

The questionnaire contains two parts: part one for demographic variables ( 8 items); part two contains the three latent constructs that are hypothesized to influence tourist satisfaction which are perceived risk with (5 items) adapted from Gallarza and Saura (2006), Jordan's image with (10 items) adapted from Schneider and Sonmez 
(1999), service climate with ( 8 items) adapted from (Schneider et al., 1998; Martin et al., 2006). Finally, tourist satisfaction with (9 items) adapted from (Olorunniwo et al, 2006; Chitty et al, 2007).

\section{Results}

\subsection{Demographic Profile of the Respondents}

The respondents' ages ranged between 20 - more than 60 years old. $55.8 \%$ were male while $44.2 \%$ were female. Most of the respondents were is married (67.3\%). Majority of The respondents from European countries with (40.9\%), followed by Africa with (31.1\%), Asia with (15\%) and 13\% from different country. Most of the respondents $(44.7 \%)$ have been working in public sector. The majority of income level is less than 1000 USD. The main reason for visiting Jordan is relaxation (65.9\%), medical treatment (18.2\%), and others $(15.9 \%)$.

\subsection{Descriptive Analysis of Variables}

The descriptive statistics of variables indicates that the four constructs, three exogenous (perceived risk, jordan image and service climate) and one endogenous (tourist satisfaction) has Cronbach alpha above 0.60 . This implies that the measurement scales for all variables are internally consistent and reliable (Nunnally, 1970). Moreover, the analysis is based on 291 valid cases being analyzed for mean and standard deviation for all the variables. Jordan's image is represented by 10 items. The mean scores are considered very high (5.89). In addition, the results show that the perceived risk is relatively moderate with mean score of 3.51 ; respondents have given more attention to the relationship between perceived risk and tourist satisfaction. Mean score for service climate is 5.39 , and the mean score for tourist satisfaction is higher at 6.33 .

Finding of this study indicate that there are 16 items remaining after Confirmatory Factor Analysis (CFA). However, some constructs have high skewness values. Therefore, normality was detected by using critical ratio (c.r) of skewness (Hair et al., 2006). Those that are above +/-3 were transformed using CDF norm function in SPSS resulting in new variable name (Coakes \& Steed, 2003). Another test taken is the composite reliability of each measure which was developed by Werts et al (1974). This test measures the reliability of a construct in the measurement model this was assessed using Nunnally (1970) guideline for assessing reliability coefficients.

The second test is the composite reliability of each measure. This was assessed using Nunnally (1970) guideline for assessing reliability coefficients. Composite reliability developed by Wertsm et al (1974), measures the reliability of a construct in the measurement model. The composite reliability is calculated by the use of the following equation:

$$
\text { Composite reliability }=\frac{\left(\sum s \tan \text { dizedloding }\right)^{2}}{\left(\sum s \tan \text { dizedloading }\right)^{2}+\sum \varepsilon j}
$$

(Source: Hair et al. 1998: 624)

The summary of the composite reliability based on the standardized factor loadings obtained from the final revised structural model is that all constructs have acceptable value above 0.60 (Nunnally, 1970). In addition, a composite reliability index that exceeds 0.70 indicates satisfactory internal consistency (Hair et al., 1998).

A composite reliability result indicates that all the measurement observed variables can be considered as reliable and acceptable as most of the constructs have value of more than .85. This result provides strong support for the construct components. Results of confirmatory factor analysis showed that the factor loadings of all observed variables or items are adequate, ranging from 0.55 to 0.98 . This indicates that all the constructs conform to the construct validity test as suggested (Hair et al., 2006). The remaining numbers of items for each construct are as follows: Jordan's image (4 items), Perceived risk (5 items), service climate (4 items), and tourist satisfaction (6 items) the total number of items are 19.

Discriminant validity is another major type of construct validity which refers to observations of constructs that should not be related to each other (Campbell \& Fiske, 1959). It represents the degree to which items differentiate among constructs or measure distinct concepts. Discriminant validity is assessed by examining the correlations between the observed potentially overlapping constructs. The observed constructs should load more strongly on their own constructs but not on other constructs. Average Variance Extracted (AVE) is the average $\mathrm{VE}$ values of two constructs. The VE is derived from the calculation of variance extracted using the following equation:

$$
\text { Variance Extracted }=\frac{\sum\left(s \tan \text { dardized } \boldsymbol{S M C ^ { 2 }}\right)}{\sum\left(s \tan \text { dardized } \boldsymbol{S M C ^ { 2 }}\right)+\varepsilon \sum j}
$$


To substantiate discriminant validity, average extracted (AVE) is compared to correlation square of the interrelated variables concerned (Fornell \& Larcker, 1981). However, Gaski (1984) recommended assessing discriminant validity in data analysis to increase the validity.

\subsection{Goodness of Fit Indices}

Indicators of CFA constructs produced a moderately good fit as indicated by the goodness of fit indices such chi-squre as CMIN/df ratio ( $<2)$; p-value $(>0.05)$; Goodness of Fit Index (GFI) of $>.95$; and Root Mean Square Error of Approximation (RMSEA) values of less than .08 (<.08) (Hair et al., 2006; Bagozzi \& Yi, 1989). Table 1 shows that the goodness of fit of revised model is better compared to the hypothesized model. This is predictable as hypothesized model could be only firmly confirmatory (Byrne, 2001).

Table 1. Goodness of fit index (Hypothesized Model)

\begin{tabular}{llllll}
\hline Variables & Jordan Image & Perceived Risk & Service Climate & Tourist Satisfaction & Hypothesized Model \\
\hline Items Remain & 4 & 5 & 4 & 6 & 19 \\
CMIN & 12.089 & 8.044 & 10.621 & 4.085 & 1814.753 \\
CMIN/DF & 2.033 & 2.022 & 5.213 & 2.002 & 22.212 \\
P-value & .087 & .050 & .010 & .186 & 0.000 \\
DF & 6 & 4 & 2 & 2 & 81.7 \\
GFI & 0.996 & 0.995 & 0.990 & 0.995 & 0.581 \\
CFI & 0.994 & 0.997 & 0.991 & 0.997 & 0.421 \\
TLI & 0.992 & 0.993 & 0.981 & 0.996 & 0.421 \\
NFI & 0.992 & 0.994 & 0.988 & 0.996 & 0.471 \\
RMSEA & .046 & .071 & .086 & .042 & .116 \\
\hline
\end{tabular}

Because the hypothesized model did not accomplish model fit $(\mathrm{p}<.000)$, therefore, the clarification of hypotheses result is based on Revised Model (RM) as shown in Table 2 which achieved model fit of p-value $=0.261(>0.05)$.

Table 2. Goodness of fit index (Revised Model)

\begin{tabular}{ll}
\hline Variables & Revised Model \\
\hline Items Remain & 10 \\
CMIN & 28.650 \\
CMIN/DF & 2.201 \\
P-value & .261 \\
DF & 14 \\
GFI & 0.991 \\
CFI & 0.998 \\
TLI & 0.997 \\
NFI & 0.982 \\
RMSEA & .021 \\
\hline
\end{tabular}

In this study the revised model produces regression standardized estimates direct effects readings (Beta) as shown in Table 3. All hypotheses are supported when all direct paths are significant and positive (C.R. values $>$ +/-1.96; p-value <0.05).

Table 3. Direct impact Revised Model (RM): Standardized regression weights

\begin{tabular}{llllllll}
\hline \multirow{2}{*}{ H. } & \multicolumn{2}{c}{ SRW } & Estimate & SE & C.R. & P & Support \\
\cline { 2 - 4 } & From & To & & & & \\
\hline H2 & RISK & SAT & -.042 & .099 & -.623 & .612 & NO \\
H1 & JOM & SAT & .547 & .123 & 5.610 & $* * *$ & Yes \\
H3 & SER & SAT & .010 & .016 & .201 & .798 & NO \\
\hline
\end{tabular}

As shown in Table 4, three exogenous variables (Jordan image, perceived risk and service climate), jointly explained $38.1 \%$ variance in tourist satisfaction. 
Table 4. Squared Multiple Correlation (SMC) results

\begin{tabular}{ll}
\hline Endogenous Variable & $\mathrm{SMC}=\mathrm{R} 2$ \\
\hline Tourist Satisfaction & .381 \\
\hline
\end{tabular}

\section{Discussion}

As mentioned previously, the results of this study try to examine the goodness of fit of the hypothesized structural model by integrating Jordan's image, perceived risk and service climate. As shown in Table 1, the hypothesized model does not achieve model fit $(\mathrm{p}$-value $=0.000, \mathrm{p}<0.001)$. This implies that hypothesized model is not supported. However, the Revised Model (RM) accomplished model fits and supports one (1) direct effect. Jordan's image was found to have a direct significant impact on tourist satisfaction where past studies have obtained similar result (Andreassen \& Lindestad, 1998; Bigne et al., 2001; Chen \& Tsai, 2007; Chi \& Qu, 2008; Xia et al., 2009) Thus, a positive relationship between Jordan's image and tourist satisfaction means that the tourists have positive satisfaction towards visiting Jordan in the future. In contrast, there are two insignificant direct effects. Perceived risk has a direct negative effect on tourist satisfaction; past studies have obtained similar result (Celik, 2008; Amoroso \& Hunsinger, 2008; Udo et al., 2008; Quintal et al., 2009; Wong \& Yeh, 2009). Thus, a negative relationship between perceived risk and tourist satisfaction exists. In addition, the results show that the perceived risk has a mean score of 3.51, which shows that respondents have given more attention to the relationship between perceived risk and tourist satisfaction. Secondly, with regards to the relationship between service climate and tourist satisfaction, the result reveals that there is a positive relationship which is similar to findings of previous studies (Choi \& Chu, 2000; Wang et al., 2004; Aydin \& Ozer, 2005; Solnet, 2006; Um et al., 2006; Rodriguez et al., 2009). Thus, there is a positive relationship between service climate and tourist satisfaction, a result that asserts that service climate is an important variable when tourists plan to visit Jordan. The study confirmed antecedents of tourist satisfaction through the examination of the model fit as an interaction to help better explain, analyze and understand international tourists' satisfaction among international tourists.

\section{Recommendations and Conclusion}

Future research should investigate the model in a different setting in the Dead Sea area, such as in the southern or northern region. Therefore, more research needs to be done on these areas in order to measure and investigate the international tourists' satisfaction in different countries. Other determinant factors need to be considered in future research such as technological factors (i.e. Internet), services and products prices, environmental factors, and infrastructural factors. More importantly, the Ministry of Tourism in Jordan should focus more on the safety of tourists, availability of modern facilities, development of better transportations avenues that could help tourists to have a faster access to all tourist sites, and tourist destinations. Subsequently, it will lead to augmentation of tourists' satisfactions towards the destination. The research examined the antecedents of satisfaction. Several direct paths are found to be significantly related to either satisfaction. One direct path is found to be significantly related; from Jordan's image to tourist satisfaction. The results showed that the Revised Model (RM) is the best model to explain the international tourists' satisfaction as compared to the Hypothesized Model.

\section{References}

Al Muala, A. M., Nik Mat, N. K., Isa, F. M., \& ALMajali, M. (2010). Assessing Actual Visit Behavior through Antecedents of Tourists Satisfaction among International Tourists in Jordan: A Structural Equation Modeling (SEM).

Alhroot, A. H. (2007). Marketing of a destination. Jordan as a case study. (Phd. Thesis). Huddersfield Uneversity, UK.

Amoroso, D. L., \& Hunsinger, D. S. (2008). Analysis of the Factors that Influence Online Purchasing. Director, 2010.

Andreassen, T. W., \& Lindestad, B. (1998). Customer loyalty and complex services. International Journal of Service Industry Management, 9(1), 7-23. http://dx.doi.org/10.1108/09564239810199923

Aydin, S., \& Ozer, G. (2005). National customer satisfaction indices: an implementation in the Turkish mobile telephone market. Marketing Intelligence \& Planning, 23(5), 486-504. http://dx.doi.org/10.1108/02634500510612654

Barsky, J. D., \& Labagh, R. (1992). A Strategy for Customer Satisfaction. Cornell Hotel and Restaurant Administration Quarterly, 33(5), 32-40. http://dx.doi.org/10.1177/001088049203300524 
Bigne, J. E., Sanchez, M. I., \& Sanchez, J. (2001). Tourism image, evaluation variables and after purchase $\begin{array}{llll}\text { behaviour: inter-relationship. } & \text { Tourism }\end{array}$ http://dx.doi.org/10.1016/S0261-5177(01)00035-8

Campbell, D. T., \& Fiske, D. W. (1959). Convergent and Discriminant Validation by the Multi-trait, Multimethod Matrix. Psychological Bulletin, 56, 81-105. http://dx.doi.org/10.1037/h0046016

Celik, H. (2008). What determines Turkish customer's acceptance of internet banking?. International Journal of Bank Marketing, 26(5), 353-369. http://dx.doi.org/10.1108/02652320810894406

Chen, C., \& Tsai, D. C. (2007). How destination image and evaluative factors affect behavioral intentions? Tourism Management, 28(4), 1115-1122. http://dx.doi.org/10.1016/j.tourman.2006.07.007

Chen, J., \& Gursoy, D. (2001). An investigation of tourists' destination loyalty and preferences. International Journal of Contemporary hospitality Management, 13, 79-86. http://dx.doi.org/10.1108/09596110110381870

Chi, C. G. Q., \& Qu, H. (2008). Examining the structural relationships of destination image, tourist satisfaction and destination loyalty: An integrated approach. Tourism Management, 29(4), 624-636. http://dx.doi.org/10.1016/j.tourman.2007.06.007

Chitty, B., Ward, S., \& Chua, C. (2007). An application of the ECSI model as a predictor of satisfaction and loyalty for backpacker hostels. Marketing Intelligence \& Planning, 25(6), 563-580. http://dx.doi.org/10.1108/02634500710819941

Choi, T. Y., \& Chu, R. (2000). Levels of satisfaction among Asian and Western travelers. The International Journal of Quality and Reliability Management, 17(2), 116-131. http://dx.doi.org/10.1108/02656710010304537

Choi, T., Liu, S., Pang, K., \& Chow, P. (2008). Shopping behaviors of individual tourists from the Chinese Mainland to Hong Kong. Tourism Management, 29, 811-820. http://dx.doi.org/10.1016/j.tourman.2007.07.009

Chu, R. (2002). Stated-importance versus derived-importance customer satisfaction measurement. Journal of Service Marketing, 16(4), 285-301. http://dx.doi.org/10.1108/08876040210433202

Coakes, S. J., \& Steed, L. G. (2003). SPSS Analysis Without Anguish. Sydney, Australia: John Wiley \& Sons.

Faulkner, B. (1992). The Anatomy of the Evaluation Process. In Evaluation of Tourism Marketing. Journal of Travel Research, 13, 6-9.

Fornell, C., \& Larcker, D. (1981). Evaluating structural equation models with unobservable variables and measurement error. Journal of Marketing Research, 48, 39-50. http://dx.doi.org/10.2307/3151312

Gallarza, M., \& Saura, I. G. (2006). Value dimensions, perceived value, satisfaction and loyalty: an investigation of university students' travel behaviour. Tourism Management, 27, 437-452. http://dx.doi.org/10.1016/j.tourman.2004.12.002

Gaski, F. M (1984). The index of consumer sentiment toward marketing. Journal of Marketing Assessment, 50(3), 71-81.

Hair, J. F., Anderson, R. E., Tatham, R. L., \& Black, W. C. (1998). Multivariate data analysis (8th ed.). Upper Saddle River, NJ: Prentice-Hall, Inc.

Hair, J. F., Black, W. C., Babin, B. J., Anderson, R. E., \& Tatham, R. L. (2006). Multivariate Data Analysis (6th ed.). Prentice Hall.

Hamid, A. A. (2007). Determinants of attitudes towards tourists, the quality of services provided in the five star hotels in Amman. (Unpublished Master Thesis). Amman Arab University for Graduate Studies.

Harahsheh, S. S. (2010). An evaluation of the image of the Hashemite Kingdom of Jordan in the British and Swedish markets and the implications for marketing the country as a tourism destination. (Unpublished $\mathrm{PhD}$ Thesis). Bournemouth University.

Homburg, C., \& Giering, A. (2001). Personal characteristics as moderators of the relationship between customer satisfaction and loyalty - An empirical analysis. Psychology \& Marketing, 18(1), 43-66. http://dx.doi.org/10.1002/1520-6793(200101)18:1<43::AID-MAR3>3.0.CO;2-I 
Iglesias, M. P., \& Guillen, M. (2004). Perceived quality and price: their impact on the satisfaction of restaurant customers. International Journal of Contemporary Hospitality Management, 16(6), 373-379. http://dx.doi.org/10.1108/09596110410550824

Jay, K., \& Suhartanto, D. (2000). Customer loyalty in the hotel industry: the role of customer satisfaction and image. International journal of contemporary hospitality management, 12(6), 346-352. http://dx.doi.org/10.1108/09596110010342559

Lin, W. B. (2008). Construction of on-line consumer behavior models: a comparative study of industries in Taiwan. International Journal of Commerce and Management, 18(2), 123-149. http://dx.doi.org/10.1108/10569210810895221

Martin, A., Kennedy, B., \& Stocks, B. (2006). Academic service climate as a source of competitive advantage: leverage for university administrators. Education Research and Perspectives, 33(1), 139.

MoTA. (2010). Statistics Ministry of Jordan Tourism and Antiquities 2000-2009: Ministry of Tourism and Antiquities.

Nunnally, J. (1970). Introduction to Psychological Measurement. New York: McGraw-Hill.

Olorunniwo, F., Hsu, M. K., \& Udo, G. F. (2006). Service quality, customer satisfaction, and behavioral intentions in the service factory. Journal of Services Marketing, 20(1), 59-72. http://dx.doi.org/10.1108/08876040610646581

Quintal, V., Lee, J. A., \& Soutar, G. N. (2009). Risk, uncertainty and the theory of planned behavior: A tourism example. Tourism Management, 1, 1-9.

Ryu, K., Han, H., \& Kim, T-H. (2007). The relationships among overall quick-casual restaurant image, perceived value, customer satisfaction, and behavioral intentions. International Journal of Hospitality Management, 27(3), 459-469. http://dx.doi.org/10.1016/j.ijhm.2007.11.001

Schneider, B., White, S. S., \& Paul, M. C. (1998). Linking service climate and customer perceptions of service quality: test of a causal model. Journal of Applied Psychology, 83, 150-163. http://dx.doi.org/10.1037/0021-9010.83.2.150

Schneider, I., \& Sonmez, S. (1999). Exploring the tourist image of Jordan. Tourism Management, 20, 539-542. http://dx.doi.org/10.1016/S0261-5177(99)00023-0

Solnet, D. (2006). Introducing employee social identification to customer satisfaction research. A hotel industry study. Managing Service Quality, 16(6), 575-594. http://dx.doi.org/10.1108/09604520610711918

Udo, G. J., Bagchi, K. K., \& Kirs, P. J. (2008). Assessing Web Service Quality Dimensions: The E-Servperf Approach. Issues in Information Systems, IX(2), 313-322.

Ueltshy, L. C., \& Krampf, R. F. (2001). Cultural Sensitivity to Satisfaction andService Quality Measures. Journal of Marketing Theory and Practice, 9(3), 14-31.

Um, S., Chon, K., \& Ro, Y. (2006). Antecedents of revisit intention. Annals of Tourism Research, 33(4), 1141-1158. http://dx.doi.org/10.1016/j.annals.2006.06.003

Wang, Y., Lo, H. P., \& Yang, Y. (2004). An integrated framework for service quality, customer value, satisfaction: Evidence from China's telecommunication industry. Information Systems Frontiers, 6(4), 325-340. http://dx.doi.org/10.1023/B:ISFI.0000046375.72726.67

Werts, C. E., Linn, R. L., \& Joreskog, K. G. (1974). Interclass reliability estimates: testing structural assumptions. Educational and Psychological Measurement, 34, 325-347. http://dx.doi.org/10.1177/001316447403400104

Wong, J., \& Yeh, C. (2009). Tourist Hesitation In Destination Decision Making. Annals of Tourism Research, 36(1), 6-23. http://dx.doi.org/10.1016/j.annals.2008.09.005

Xia, W., Jie, Z., Chaolin, G., \& Feng, Z. (2009). Examining Antecedents and Consequences of Tourist Satisfaction: A Structural Modeling Approach. Tsinghua Science \& Technology, 14(3), 397-406. http://dx.doi.org/10.1016/S1007-0214(09)70057-4

Yoo, D. K., \& Park, J. A. (2007). Perceived service quality: Analyzing relationships among employees, customers, and financial performance. International Journal of Quality \& Reliability Management, 24(9), 908-926. http://dx.doi.org/10.1108/02656710710826180 